\title{
Physiopathology of intratendinous calcific deposition
}

Francesco Oliva ${ }^{1}$, Alessio Giai Via ${ }^{1}$ and Nicola Maffulli ${ }^{2^{*}}$

\begin{abstract}
In calcific tendinopathy (CT), calcium deposits in the substance of the tendon, with chronic activity-related pain, tenderness, localized edema and various degrees of decreased range of motion. $C T$ is particularly common in the rotator cuff, and supraspinatus, Achilles and patellar tendons. The presence of calcific deposits may worsen the clinical manifestations of tendinopathy with an increase in rupture rate, slower recovery times and a higher frequency of postoperative complications. The aetiopathogenesis of $\mathrm{CT}$ is still controversial, but seems to be the result of an active cell-mediated process and a localized attempt of the tendon to compensate the original decreased stiffness. Tendon healing includes many sequential processes, and disturbances at different stages of healing may lead to different combinations of histopathological changes, diverting the normal healing processes to an abnormal pathway. In this review, we discuss the theories of pathogenesis behind $\mathrm{CT}$. Better understanding of the pathogenesis is essential for development of effective treatment modalities and for improvement of clinical outcomes.

Keywords: Calcific Tendinopathy, Calcific Deposits, Tendons, Review
\end{abstract}

\section{Introduction}

In calcific tendinopathy $(\mathrm{CT})$ calcium deposits in the substance of the tendon. CT is particularly common in the rotator cuff tendons (RCTs) and supraspinatus tendon, and Achilles tendon and patellar tendon. CT of the rotator cuff is common in Caucasian populations, with a reported prevalence of $2.7 \%$ to $22 \%$, mostly affecting women between 30 and 50 years. The most frequently

\footnotetext{
* Correspondence: n.maffulli@qmul.ac.uk

${ }^{2}$ Centre for Sports and Exercise Medicine Queen Mary University of London, Barts and The London School of Medicine and Dentistry, Mile End Hospital, 275 Bancroft Road, London, E1 4DG, UK

Full list of author information is available at the end of the article
}

involved tendon is the supraspinatus tendon, and in $10 \%$ of patients the condition is bilateral (Figure 1) [1]. The nomenclature of this condition is confusing, and, for example, in the shoulder terms such as calcific periarthritis, periarticular apatite deposition, and calcifying tendinitis have been used [2]. We suggest to use the terms 'calcific tendinopathy', as it underlines the lack of a clear pathogenesis when the process is located in the body of tendon, and 'insertional calcific tendinopathy', if the calcium deposit is located at the bone-tendon junction.

Calcific insertional tendinopathy of the Achilles tendon manifests in different patients populations, including young athletes and older, sedentary and overweight individuals [3]. Usually, radiographs evidence ossification at the insertion of the Achilles tendon or a spur (fish-hook osteophyte) on the superior portion of the calcaneus. CT in this location is often associated with retrocalcaneal bursitis or Haglund's deformity. The incidence of insertional tendinopathy of the Achilles tendon is not clear. The incidence varies from $5 \%$ to the most common presentation in athletes [3]; calcifications of the main body of the tendon are at best uncommon (Figure 2). CT of the patellar tendon is rare, and most patients with patellar tendinopathy show no evidence of ossification [4].

Most of the current treatment modalities are neither effective nor evidence-based because of our poor understanding on the underlying pathogenesis of CT. We review the present knowledge on this topic to stimulate further research.

\section{Clinical manifestation}

Clinical manifestations of the calcific process within the tendons include chronic activity-related pain, tenderness, localized edema and various degrees of decreased range of motion (ROM). CT of the rotator cuff shows a tendency toward spontaneous resorption of the deposits and symptoms often resolve spontaneously, although some authors described persistent pain at long time follow-up and persistent reduction of ROM [5,6]. Osteolysis of the 


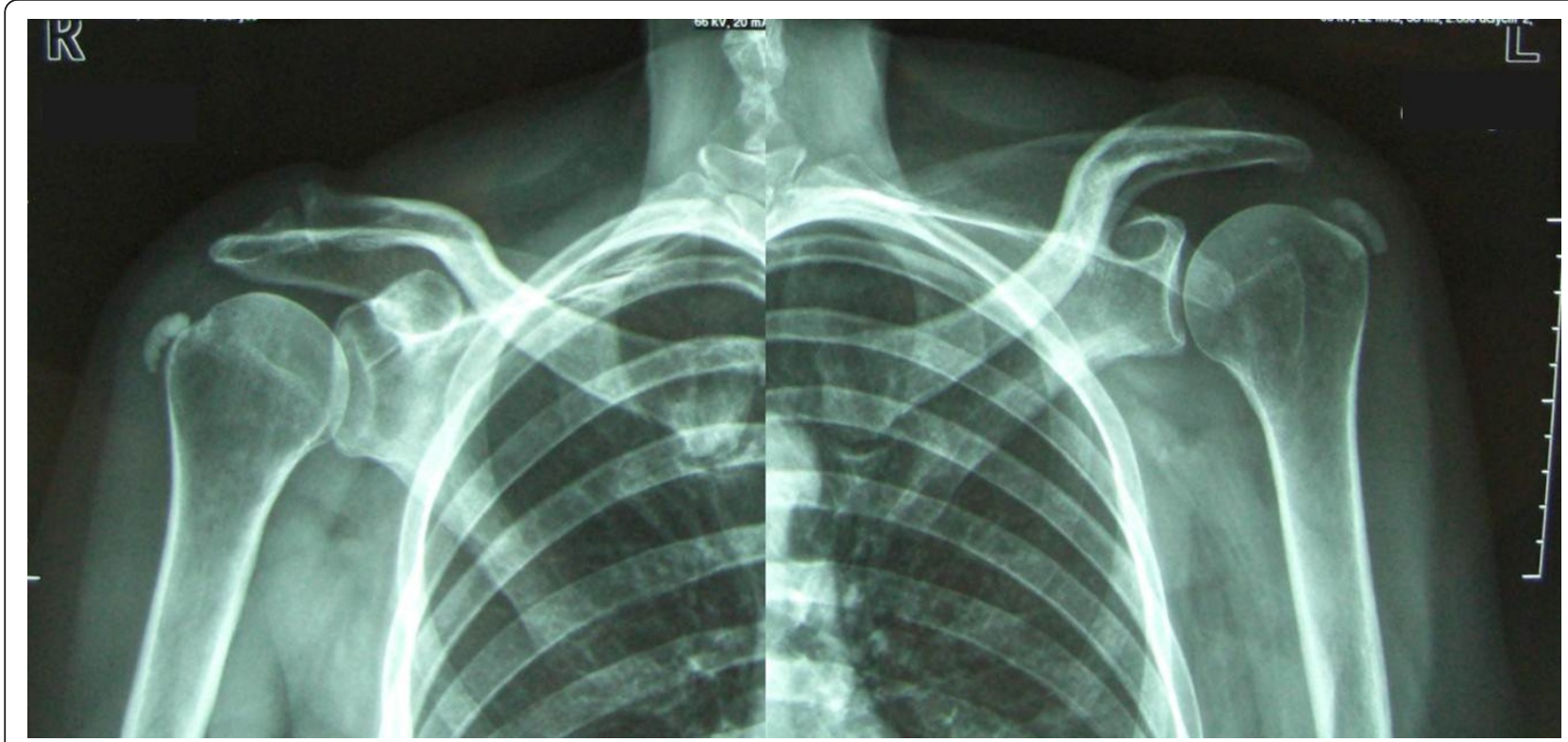

Figure 1 Bilateral calcific tendinopathy (CT) of the shoulder.

greater tuberosity is an uncommon and distinctive form of CT of the shoulder, and is associated with significantly poorer clinical and functional outcome both before and after surgical treatment [7]. Microscopic calcifications which are not detectable at plain radiography can also occur in chronic tendinopathy. A histological study showed high incidence of small calcium deposits in tendinopathic supraspinatus tendons [8]. Microscopic calcium deposits are frequent also in diabetic patients [9].

The clinical course of insertional CT has been poorly investigated, although experience suggests that pain seems to improve in older patients even though the insertional calcification persists. Generally, the presence of calcific deposits worsens the clinical manifestations of

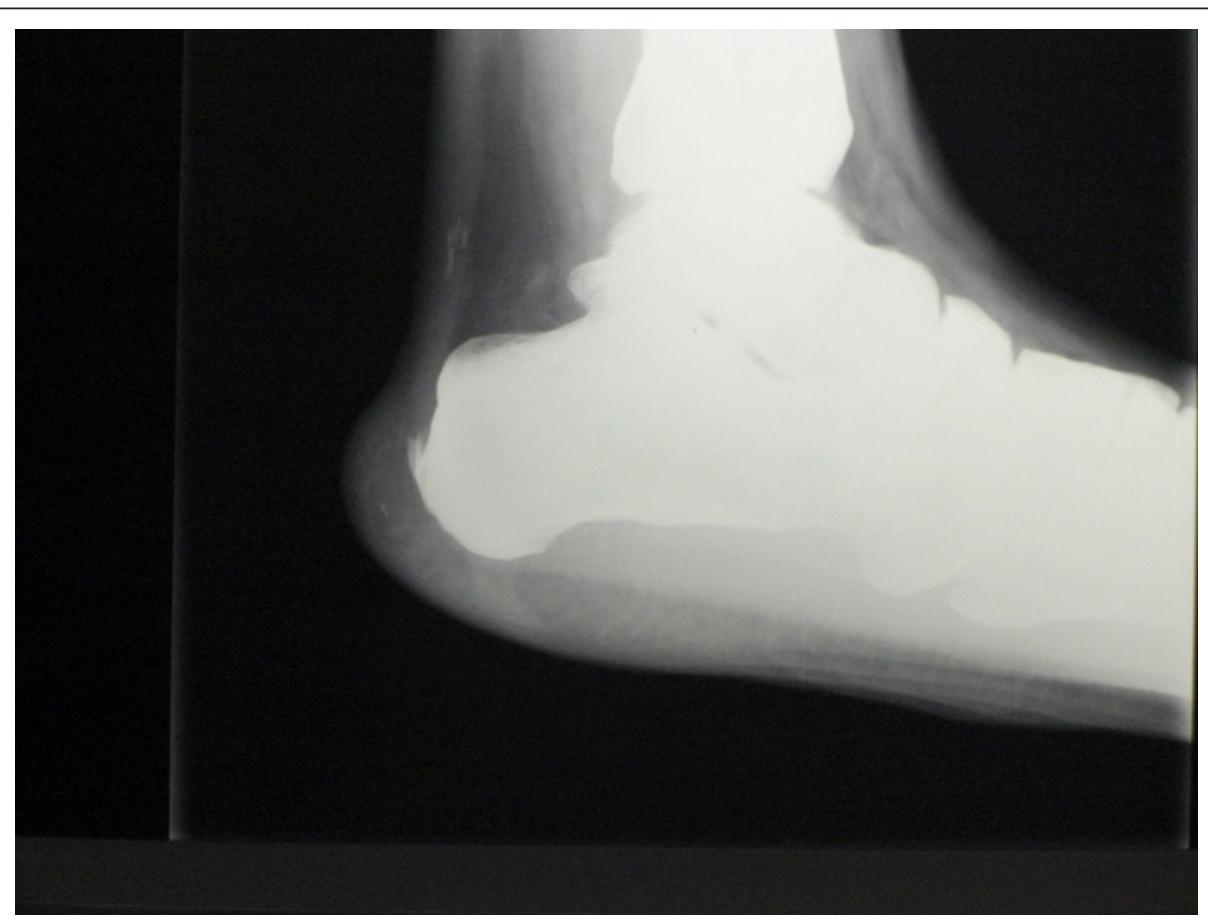

Figure 2 Insertional calcific tendinopathy (CT) of the Achilles tendon associated with $\mathrm{CT}$ of the main body of the tendon. 
tendinopathy with an increase in rupture rate, slower recovery times and a higher frequency of post-operative complications [10].

\section{Historical review}

As previously discussed, the nomenclature of $\mathrm{CT}$ is confusing, perhaps in part because of the many terms classically used to describe localized deposits of calcium in tendons [11], including calcifying tendinitis, calcific tendinitis, calcified tendinitis, calcareous tendinitis, tendinosis calcarea, calcific periarthritis, periarticular apatite deposit [10]. Some of them emphasise the extra-articular location of the deposit, others mention the nature of the compound found in the calcification or the process that might explain its deposition.

At the beginning of the 1950s, it was clear that local degeneration of the involved tendon precedes the deposition of calcium salts [11], and that there may be a constitutional predisposition.

Sandstrom, in 1938, speculated that necrosis of the tendon secondary to local ischemia and vascular changes was the first step to promote deposition of calcified material [12]. Bishop believed that repetitive minor trauma could induce rupture of the fibers of the supraspinatus tendon, hyaline degeneration and the deposition of calcium in the injured tendon [13]. The hypothesis was later supported by Bosworth and colleagues [14]. Urist et al. and Uhthoff et al. suggested the occurrence of an initial cartilage metaplasia of the tendon, followed by an active multifocal and cell-mediated calcifying process $[15,16]$. Recently, Mohr and Bilger described the process as beginning with the necrosis of tenocytes with concomitant intracellular accumulation of calcium, often in the form of microspheroliths or psammomas [17].

\section{Mineral components}

Specimens of RCTs obtained during surgery consist of a gritty mass of sandy material or a toothpaste-like fluid, and the deposits were described as a white amorphous mass composed of many small round or ovoid bodies. Later, X-ray diffraction and infrared spectrometry and other techniques identified the material of calcific deposits as calcium carbonate apatite [18-20]. Computed tomography studies of patellar tendon revealed the three-dimensional structure of calcific deposits, which have a porous structure throughout the tendon [18]. Few investigations have been performed on the role of the types of carbonated apatite, although they have been reported to be a single component in the calcific deposits [21]. Two different types of carbonate apatite compose the calcific deposits, according to the position which carbonate ions $\left(\mathrm{CO}_{3}^{2-}\right)$ occupy in the hydroxyapatite (HAP). They are defined as A-type carbonate apatite and B-type carbonate apatite [22]. Gartner et al. [23] observed that the macroscopic differences of calcific deposits were not reflected in the mineralogical structure, and neither chemical compositional change nor a change in the crystal lattice was observed. They stated that no chemical dissolution process of the inorganic material was responsible for the resorption activity in the acute phase. More recently Chiou et al. studied the chemical components in CT of the RCTs, and they observed that different quantities of A- and B-type carbonated apatite changed in the formative, resting and resorption phases [24]. They noted reduced amounts Atype carbonate apatite and increased amounts located in the B positions during the process of progressive calcification. The same Authors classified calcific depositions into four shapes according to ultrasonographic findings: an arc shape, a fragmented or punctuated shape, a nodular shape, and a cystic shape. They also found a statistically significant association between the morphology of the calcified deposits and the clinical symptoms of the affected shoulder (Table 1).

Recently, matrix vesicles have been isolated in mature porcine patellar tendons [25]. Matrix vesicles are small extracellular organelles which are involved in mineralization of the extracellular matrix in many tissues, including bone and cartilage [26]. Previous studies demonstrate the presence of matrix vesicles near calcific deposition of the RCTs [16,27], and recently they have been isolated also in the extracellular matrix of normal patellar tendons [25]. The authors pointed out the importance of extracellular matrix vesicles in pathogenetic mechanism of $\mathrm{CT}$. In the normal matrix, the vesicles are inhibited from mineralizing, but, in pathological conditions, such as injuries or matrix degeneration

Table 1 Correlation between morphology, progressive calcification process and symptoms of the mineral components of calcific tendinopathy (CT) of the rotator cuff, proposed by Chiou [24].

\begin{tabular}{llll}
\hline Calcific stage & Phase & Morphologic shape of calcific deposition & Clinical symptoms \\
\hline Pre-calcific stage & Correlation not evaluated & & Mild pain \\
Calcific stage & Formative phase & Arc or fragmented/punctuated & Moderate to severe pain \\
& Resting phase & Nodular & Cystic \\
& Resorptive phase & & Severe pain \\
Post-calcific stage & Correlation not evaluated & & \\
\hline
\end{tabular}


secondary to age or diabetes, they may be permitted to mineralize.

\section{Theories of pathogenesis}

The aetiopathogenesis of CT is largely unknown, especially because it remains difficult to clarify the steps which induce crystal deposition into the tendon. Furthermore, biopsies of the pathologic RCTs are obtained only towards the end of the natural history of the condition, when patients are symptomatic [16]. Many different theories have been developed (see also Table 2).

\section{Reactive Calcification}

Uhthoff and coworkers hypothesized that a favorable environment permits an active process of cell-mediated calcification, usually followed by spontaneous phagocytic resorption [28]. They describe four stages in the calcifying process of the rotator cuff: precalcific phase, calcific phase, resorptive phase, and repair phase. All phases may occur concomitantly in the same tendon. The precalcific stage involves fibrocartilaginous metaplasia within the tendon. In the second stage, the formative phase, calcific deposits are formed. This stage is subdivided into three phases: formative, resting, and resorptive. Calcium crystals are deposited primarily in matrix vesicles that coalesce to form large foci of calcification separated by chondrocytes and fibrocartilaginous tissue septae. The resting phase occurs when fibrocollagenous tissue borders the foci of calcification, indicating termination of deposition. The resorptive phase is marked by the appearance of thin-walled vascular channels at the periphery of the deposit. Macrophages and multinucleated giant cells then surround the deposit and phagocytose debris with calcium removal. In this phase, the deposit exhibits a thick, creamy, or toothpaste-like material that is often under pressure. The final stage involves an attempt by tendon to heal. Nakase et al. [29] clarified the nature of the multinucleated cells located near the calcium deposits. These were positive for cathepsin K [29], showing a typical osteoclast phenotype. Cathepsin $\mathrm{K}$ is a protease, it is a member of the peptidase $\mathrm{C} 1$ protein family, is predominantly expressed in osteoclasts, and it is involved in bone remodeling and resorption [30]. Some years after these proposals were made, osteopontin was observed in cells surrounding tendon calcifications [31,32]. Osteopontin is a member of the small integrin-binding ligand $\mathrm{N}$-linked glycoprotein glycoprotein (SIBLING) family first identified in 1986 in osteoblasts. It plays important roles in many physiological and pathological processes, including wound healing and bone remodeling [33], but its role in CT has not been clarified [32].

\section{Endochondral Ossification}

Achilles and patellar tendon calcifications are formed by a process resembling endochondral ossification, with bone formation and remodeling mediated by population of osteoblasts and osteoclasts.

Benjamin and coworkers proposed a model of insertional Achilles CT based on a rat study [34]. They suggested that insertional CT could develop by endochondral ossification of fibrocartilage at the enthesis of the Achilles tendon. The calcific process begins in the enthesis and grows into the tendon. Fibrocartilage cells appear by metaplasia from tenocytes. The fibrocartilage is then eroded, and blood vessels invade the rows of fibrocartilage cells from the underlying bone marrow. Finally, bone is deposited and the spur is formed. No inflammatory cells or microtears were identified. The authors believe that the increased surface at the tendon-bone junction may represent an adaptive mechanism to increased mechanical loads.

Lui et al. studied the histological features of collagenase-induced patellar tendon ossification in a rat model [35]. Many chondrocyte-like cells and the absence of infiltration of inflammatory cells were observed around the calcific deposits. They found a marked loss of collagen type I and an increase of collagen type II and type $\mathrm{X}$, which occurred mainly at the chondrocyte-like cells and their surrounding matrix in the calcific deposits. Collagen type II is typical of cartilage and fibrocartilage, and it is resistant to compressive stresses. Type $\times$ collagen is a short chain collagen which has been associated with calcific cartilage and/or the expression of the hypertrophic chondrocyte phenotype. It is a marker of endochondral ossification. The same authors subsequently described an increased expression of collagen

Table 2 Different theories about etiopathogenesis of calcific tendinopathy (CT).

\begin{tabular}{|c|c|c|c|}
\hline Type & Cause & Reference(s) by first author & Year(s) \\
\hline \multirow[t]{3}{*}{ Degenerative calcification } & Vascular ischemia & Sandstrom [12] & 1938 \\
\hline & Repetitive trauma & Bishop [13] and Bosworth [14] & 1939, 1941 \\
\hline & Necrosis of tenocytes and intracellular calcium accumulation & Mohr [17] & 1990 \\
\hline Reactive calcification & Active cell mediated process & Uhthoff [27] & 1997 \\
\hline Endochondral ossification & Endochondral ossification of fibrocartilage at the enthesis of the tendon & Benjamin [34] & 2000 \\
\hline Chondral metaplasia & Erroneous differentiation of tendon-derived stem cells (TDSCs) & Rui [46] & 2011 \\
\hline
\end{tabular}


type III and a high collagen type III/collagen type I ratio [36]. The increase of collagen type III coincided with thinner, less organized and weaker tendon. Histological specimens of insertional calcific tendinopathy of Achilles tendons showed a greater intensity of staining for collagen type III than normal tendons [37], and higher than normal expression of collagen types III mRNA was detected high in human Achilles tendinopathy [38]. Chondrocyte markers were also evidenced in the clinical samples of calcific insertional Achilles tendinopathy and in rotator cuff tendinopathy $[37,39]$.

\section{Chondral Metaplasia}

Other authors thought that ectopic bone derives from metaplasia of tendon cells into osteogenic cells. Injection of recombinant human bone morphogenetic protein-2 (rhBMP-2) [40] into the tendon increased ectopic bone formation, indicating that the tendon consisted of cells that were responsive to BMP [41] and were capable of differentiating along the chondro-osseous pathway.

Mesenchymal stem cells are present in tendon tissues [42]. Human and mouse tendons hold cells with universal stem cell characteristics which could differentiate into chondrocytes and osteoblasts [43]. Rui et al. isolated Tendon-Derived Stem Cells (TDSCs) from the flexor tendon and patellar tendon of rats $[44,45]$. They proposed that chondral metaplasia and ectopic ossification may be caused by erroneous differentiation of tendon cells [46].

Which condition or stimulus is able to cause this erroneous differentiation of TDSCs? Many proteins could be involved in tendon degeneration, calcification and rearrangement processes, playing different roles in the various phases of calcification and resorption. Among the possible candidates are bone morphogenetic proteins (BMPs) and transglutaminases (TGs). Recently, Zang and Wang suggested that BMP-2-mediated effects on human TDSCs may contribute to the formation of calcific deposits in CT [47]. We observed an increased expression of osteopontin, cathepsin K and TG2 mRNA in the calcific areas of the supraspinatus tendon as compared to what observed in the normal tissue [48]. TG2 is ubiquitously expressed, and plays a role in a variety of cellular processes, including the crosstalk between macrophages and apoptotic cells, glucose tolerance and other processes. It is also important in maintaining the structural integrity of tendons and it could be involved in tendon repair [49]. The increased expression of osteopontin and TG2 could thus be compatible with their increased production in the calcific area, probably by osteoclast-like cells involved in the resorptive phase [29].

The mRNA and protein expression of major proteoglycans of extracellular matrix, including decorin, aggrecan, biglycan and fibromodulin and their relationship with ectopic chondrogenesis, ossification and loss of matrix organization, has been observed in a calcific tendinopathy model [36]. Decorin, aggrecan, biglycan and fibromodulin are small leucine rich repeated proteoglycans (SLRPs), which participate in collagen-fibril formation, and their expression patterns are altered in chronic tendinopathy [50]. Decorin is a component of connective tissue, binds to type I collagen fibrils, and plays a role in matrix assembly [51]. It is the most abundant SLRP found in tendon mid-substance. Aggrecan and biglycan are common in the fibrocartilaginous regions of the enthesis. Aggrecan plays an important role in the adaptation to compressive loads. Fibromodulin participates in the assembly of the extracellular matrix, and it interacts with type I and type II collagen fibrils [52]. A sustained or increased expression of decorin, aggrecan, biglycan and fibromodulin was found in this calcified tendinopathy model [36]. However, the presence of ectopic calcification in Achilles, patellar and quadriceps tendons was also reported in biglycan and fibromodulin knockout mice [53]. Another important feature of SLRPs is their ability to modulate the activity of the resident cell population by binding and sequestering growth factors $[54,55]$. The differentiation of tendon progenitor cells into chondrocytes and bone cells was modulated by the expression of biglycan and fibromodulin [56]. In normal tendon healing, TDSCs would proliferate and differentiate into tenocytes, but in particular conditions, they can differentiate into chondrocytes or osteoblasts, causing the deposition of the 'wrong' extracellular matrix and calcific deposits, resulting in failed healing and pain. The mechanism leading to the erroneous differentiation of TDSCs is not clear. It could be modulated by the expression of biglycan and fibromodulin, and by the expression of chondro-ostogenetic BMPs, such as BMP-2, BMP-4 and BMP-7, which were overexpressed in CT models [57]. Rui et al. therefore hypothesized that the erroneous differentiation of TDSCs into chondrocytes or osteoblasts instead of tenocytes could be the pathogenetic mechanism of calcifying tendinopathy [46]. Aberrant differentiation of stem cells has been postulated to be the cause of other disorders, including vascular calcification [58], skin calcification [59] and skeletal calcification [60].

\section{Predisposing Factors}

An association between $\mathrm{CT}$ and diabetes and thyroid disorders has been shown, but the precise mechanism is still unknown [1]. Patients with associated endocrine disorders present earlier onset of symptoms, longer natural history, and they undergo surgery more frequently compared to a control population $[61,62]$. More than $30 \%$ of patients with insulin-dependent diabetes have tendon calcification [63]. The exposure of proteins to 
high levels of sugar moieties cause the glycosylation of several extra-cellular matrix proteins, which can modify the extracellular matrix by cross-linking proteins. In an animal study, tenocytes obtained from porcine patellar tendon have been incubated with glycated type I collagen, which increased Tg activity. This may represent an additional pathway mediating pathologic changes and could contribute to CT in diabetes [62].

A familial predisposition and inherited genetic components have also been postulated as a cause of CT in some circumstances [64-67]. Variants within the COL5A1 [68], tenascin C [69] and matrix metalloproteinase 3 (MMP3) genes [70] are associated with increased risk of Achilles tendon injuries. CT of the RCTs have been observed in children, and hence it cannot be related to degenerative changes [71] (Figure 3). Therefore, some genetic variants could modify the susceptibility of tendons to the matrix abnormalities observed in tendinopathy [72].

\section{Discussion and Future perspectives}

The aetiopathogenesis of CT is still controversial, especially because it remains difficult to clarify the first steps causing this condition and those involved in the development of calcifications.

Rather than being formed by precipitation of inorganic ions, CT results from an active cell-mediated process in which resident progenitor cells with multidifferentiation potential may play a determinant role [73].

Many different factors such as acute injury, repetitive microtrauma, and chemical-induced injury may cause damage to the tendon and start the natural healing process. Tendon healing includes many sequential processes such as matrix synthesis and remodeling, synthesis of pro-inflammatory cytokines, neovascularization, neural modulations, recruitment of healing cells, multipotent cells, TDSCs, proliferation, apoptosis [74]. Disturbances at different stages of healing may lead to different combinations of histopathological changes. The normal healing processes are then diverted onto an abnormal pathway (Figure 4). Clinical features such as chronic pain, swelling, functional limitations and tendon ruptures are the consequences.

Since ossified tendons will have increased stiffness, ossification can be seen as a localized attempt to compensate for the original decreased stiffness of the weak tendon. It is possible that the erroneous differentiation of tendon progenitor cells into chondrocytes or osteoblasts instead of tenocytes may contribute to the pathogenesis of CT. The mechanism leading to the erroneous differentiation of TDSCs is not completely understood. Probably, the expression of BMPs, biglycan, fibromodulin and an unfavorable micro-environment induced by overuse modify the natural healing process of the tendon. Conservative management modalities such as non-steroidal anti-inflammatory drugs (NSAIDs) or corticosteroids are often prescribed, and may further influence the pathways of the failed healing [75]. NSAIDs could modulate tendon cell proliferation [76,77], the expression of extracellular matrix components [78] and degradative enzymes in cells culture studies [46]. Corticosteroids can induce a

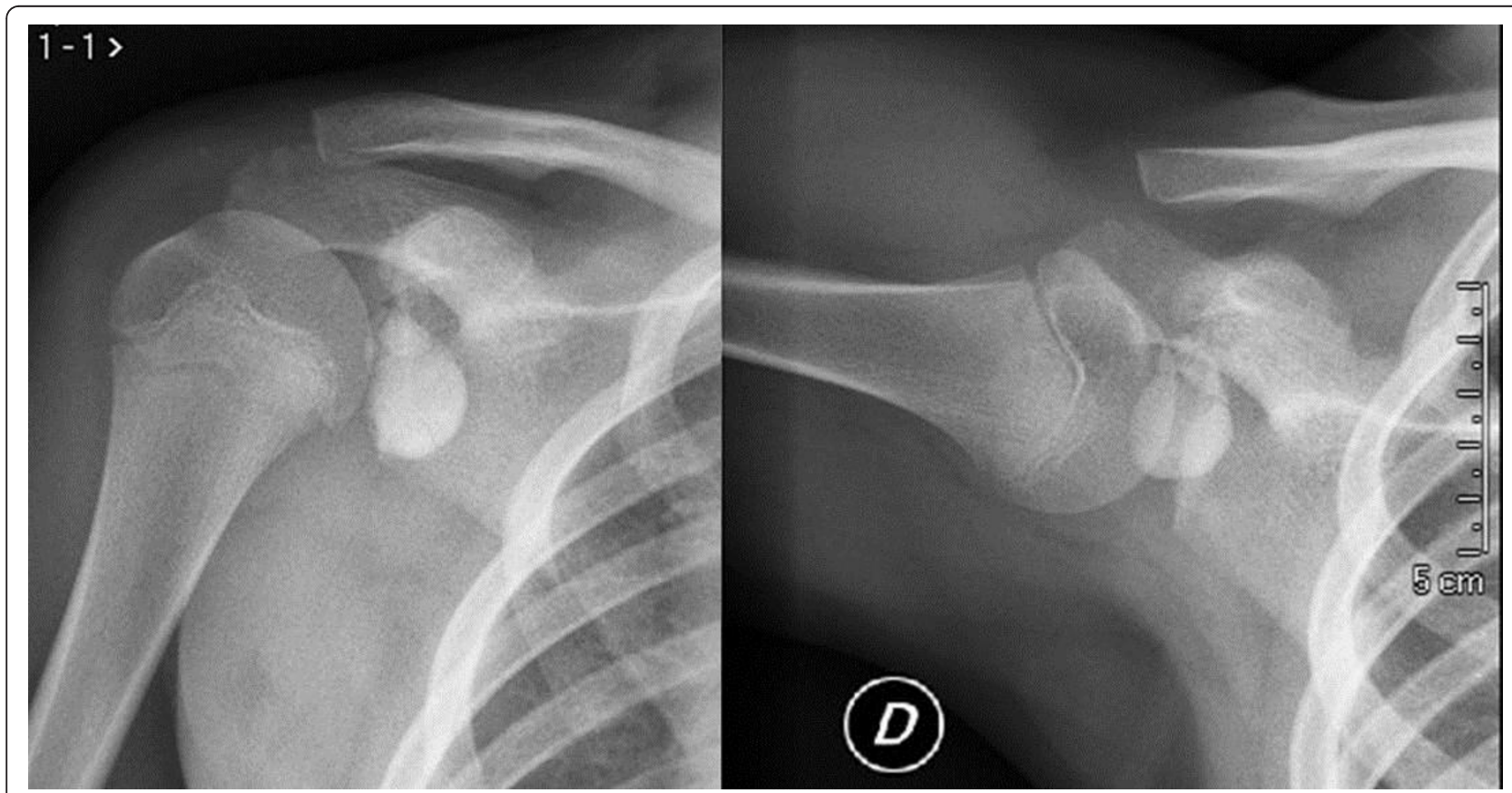

Figure 3 Calcific tendinopathy (CT) of the subscapularis tendon in a 13-years-old boy. 


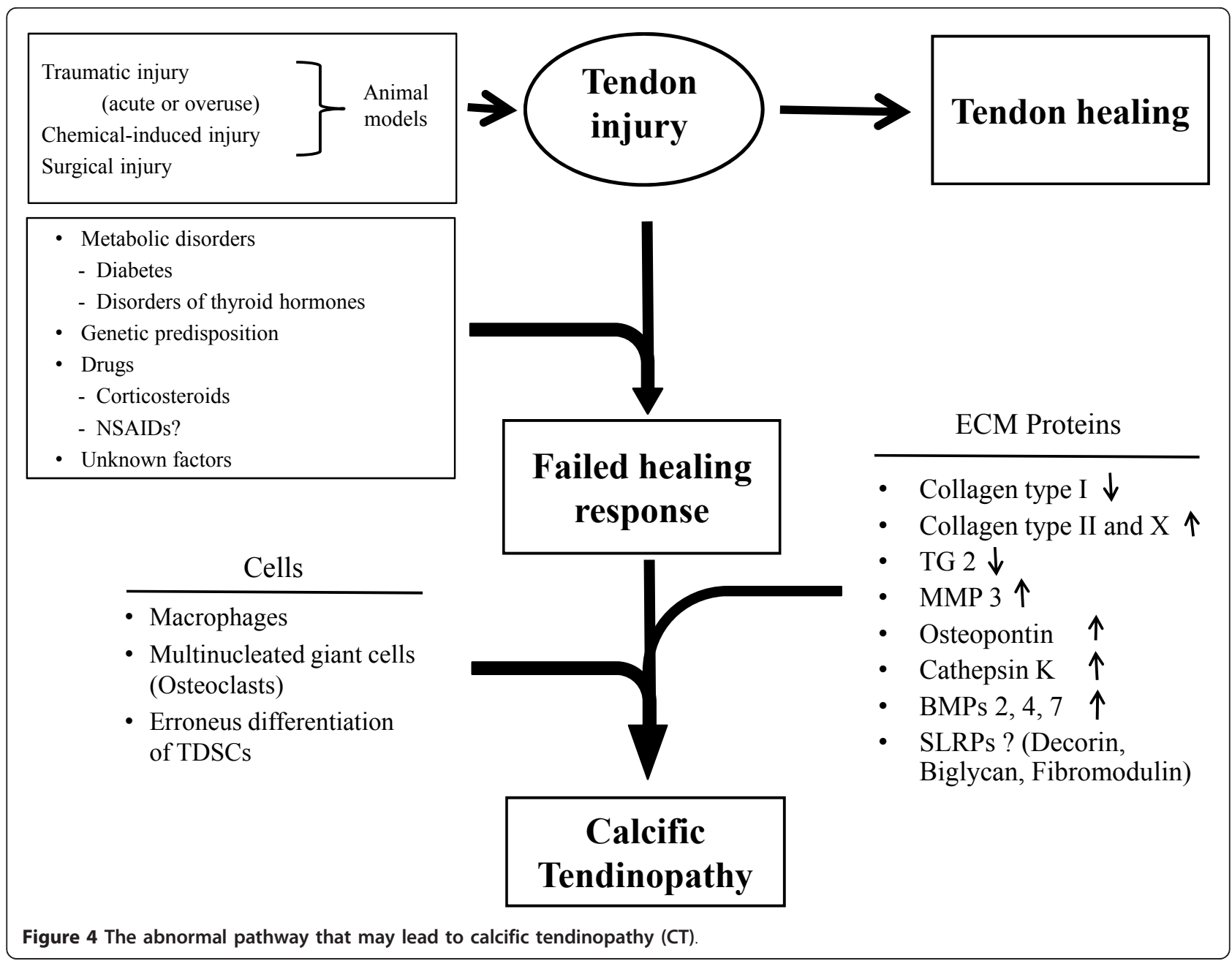

fibrocartilaginous phenotype in tendon cells [78], and induce osteogenic differentiation in human spinal ligament derived cells [79].

Many questions remain unanswered about the pathogenesis of CT. Calcium carbonate apatite appears the only component of calcific deposits, but inorganic component of Achilles and patellar CT has been less investigated than CT of the RCTs. Histological and imaging studies show that the three-dimensional structure of calcific deposits is quite different. Calcific depositions in the RCTs appear as a toothpaste-like fluid, while calcific deposits in the Achilles and patellar tendons have a porous structure [35] and a vascular core [34]. Therefore, we can speculate that their mineralogical structure could also be different.

'Calcific tendinopathy' and 'insertional calcific tendinopathy' are caused by two distinct pathogenetic mechanisms. In RCTs, degenerative changes in the extracellular matrix seem to play an important role for the formation of calcific deposits. The pathogenesis of CT involves matrix vesicles, macrophages and multinucleated giant cells with a typical osteoclast phenotype, producing a toothpaste-like material $[25,29]$. No vascular invasion has been documented. This process has not been observed in other tendons. Recently, Gohr et al. elucidated the role of matrix vesicles also in the patellar tendon [25], but, as the enthesis was removed, this model is more similar to a CT of the main body of the tendon than to an insertional CT. We also think that degenerative changes cannot be solely responsible, because we are not able to explain the deposition of calcium salt in twin brothers and children only with a reactive degenerative theory $[65,66,71]$.

The mechanism of insertional CT has been clarified by Benjamin and coworkers, and essentially accepted worldwide [34] (Table 3). Increased vascularity in insertional Achilles tendinopathy was observed also by other authors [37].

CT of the rotator cuff has been investigated with histological studies of specimens obtained from human biopsies, while the study of CT of Achilles and patellar tendons is based on animal models of collagenase-induced tendinopathy. Therefore, we do not know whether the pathogenesis 
Table 3 Pathogenetic models proposed for calcific tendinopathy (CT) of rotator cuff tendons (RCTs) and insertional CT of the Achilles tendon.

\begin{tabular}{|c|c|c|c|c|}
\hline Stage & Cells & Extracellular matrix & Blood vessels & Inflammatory cells \\
\hline \multicolumn{5}{|c|}{ CT model proposed by Uhthoff [28] for the rotator cuff: } \\
\hline $\begin{array}{l}\text { Pre-calcific } \\
\text { stage }\end{array}$ & $\begin{array}{l}\text { Chondrocyte-like } \\
\text { cells }\end{array}$ & $\begin{array}{l}\text { Fibrocartilaginous metaplasia, presence of } \\
\text { calcium crystals collected into matrix vesicles }\end{array}$ & None & None \\
\hline \multicolumn{5}{|l|}{$\begin{array}{l}\text { Calcific } \\
\text { stage: }\end{array}$} \\
\hline $\begin{array}{l}\text { Formative } \\
\text { phase }\end{array}$ & $\begin{array}{l}\text { Chondrocyte-like } \\
\text { cells }\end{array}$ & $\begin{array}{l}\text { Multifocal calcific deposits separated by } \\
\text { fibrocollagenous tissue or fibrocartilage }\end{array}$ & None & None \\
\hline $\begin{array}{l}\text { Resting } \\
\text { phase }\end{array}$ & $\begin{array}{l}\text { Chondrocyte-like } \\
\text { cells }\end{array}$ & $\begin{array}{l}\text { Fibrocollagenous tissue borders the foci of } \\
\text { calcification }\end{array}$ & None & None \\
\hline $\begin{array}{l}\text { Resorptive } \\
\text { phase }\end{array}$ & $\begin{array}{l}\text { Chondrocyte-like } \\
\text { cells }\end{array}$ & $\begin{array}{l}\text { Deposits of a thick, creamy, toothpaste-like } \\
\text { material under pressure appear }\end{array}$ & $\begin{array}{l}\text { Vascular channels near the } \\
\text { calcific deposits }\end{array}$ & $\begin{array}{l}\text { Macrophages and multinucleated } \\
\text { giant cells cathepsin K-positive [22] }\end{array}$ \\
\hline $\begin{array}{l}\text { Post- } \\
\text { calcific } \\
\text { stage }\end{array}$ & Fibroblast & $\begin{array}{l}\text { Granulation tissue, deposition of type III } \\
\text { collagen }\end{array}$ & $\begin{array}{l}\text { Capillaries surround the } \\
\text { calcific deposits }\end{array}$ & Multinucleated giant cells [22] \\
\hline \multicolumn{5}{|c|}{ Model proposed by Benjamin [34] for insertional CT of Achilles tendon: } \\
\hline Early stage & $\begin{array}{l}\text { Chondrocytes and } \\
\text { fibrocartilage cells }\end{array}$ & Fibrocartilage metaplasia & None & None \\
\hline $\begin{array}{l}\text { Second } \\
\text { stage }\end{array}$ & Few chondrocytes & $\begin{array}{l}\text { Erosion of calcaneal cartilage. Fibrocartilage } \\
\text { metaplasia of tendon matrix. }\end{array}$ & $\begin{array}{l}\text { Blood vessels invade the } \\
\text { calcaneal fibrocartilage }\end{array}$ & None \\
\hline $\begin{array}{l}\text { Bony spur } \\
\text { formation }\end{array}$ & $\begin{array}{l}\text { Few fibrocartilage } \\
\text { cells }\end{array}$ & The original cartilage has disappeared & $\begin{array}{l}\text { New bone is deposited } \\
\text { around the blood vessels }\end{array}$ & None \\
\hline
\end{tabular}

of CT of the rotator cuff can be compared to CT of the Achilles and patellar tendons. Moreover, no pathogenetic studies on the rotator cuff have been published since the late 1970s, and no animal CT studies are present in literature [80]. We do not know why the calcific deposits of the rotator cuff involve the main body of the tendon, while the most common presentation of CT in the Achilles tendon is insertional. Animal models of CT of RC seem necessary to understand its pathogenesis. No histological and epidemiological studies on CT of the main body of Achilles tendon are published.

Furthermore, no clinical or imaging classification has been published in the literature, except for the CT of RCTs [1]. Also, it is not clear whether the gross morphological anatomy of tendons (for example, the $\mathrm{RC}$ is a flat tendon, while the Achilles tendon is cylindrical) plays a role.

The involvement of mesenchymal stem cells (MSCs) in the pathogenesis of the CT process [46] and the role of autologous growth factors have been postulated, but not clarified $[54,55]$.

While emerging data seem to indicate an association between tendinopathies and endocrine disorders such as diabetes, hypercholesterolemia, hypertriglyceridemia, thyroid disorders, and estrogen levels alterations [81,82], the association with CT is unclear, and no physiopathological investigations have been performed.

\section{Conclusions}

The aetiopathogenesis of CT is still controversial, but it seems to be the results of an active cell-mediated process. We advocate use of the terms 'calcific tendinopathy' and 'insertional calcific tendinopathy' to differentiate conditions that seem to be caused by two different pathogenetic mechanisms. Better understanding of the pathogenesis is essential for development of effective treatment modalities and for the improvement of clinical outcomes.

\section{Author details}

${ }^{1}$ Department of Orthopaedics and Traumatology, University of Rome 'Tor Vergata' School of Medicine, Viale Oxford 81, Rome, Italy. ${ }^{2}$ Centre for Sports and Exercise Medicine Queen Mary University of London, Barts and The London School of Medicine and Dentistry, Mile End Hospital, 275 Bancroft Road, London, E1 4DG, UK.

\section{Authors' contributions}

FO and NM conceived the study. FO and AGV undertook the literature search. AGV wrote the first draft. All the authors revised the manuscript, and approved the final draft

\section{Competing interests}

The authors declare that they have no competing interests.

Received: 5 April 2012 Accepted: 23 August 2012

Published: 23 August 2012

\section{References}

1. Oliva F, Via AG, Maffulli N: Calcific tendinopathy of the rotator cuff tendons. Sports Med Arthrosc 2011, 19:237-243.

2. Faure G, Daculsi G: Calcified tendinitis: a review. Ann Rheum Dis 1983, 42:49-53.

3. Krishna Sayana M, Maffulli N: Insertional Achilles tendinopathy. Foot Ankle Clin 2005, 10:309-320.

4. Coleman BD, Khan KM, Kiss ZS, Bartlett J, Young DA, Wark JD: Open and arthroscopic patellar tenotomy for chronic patellar tendinopathy. A retrospective outcome study. Am J Sports Med 2000, 28:183-190. 
5. Chan R, Kim DH, Millett PJ, Weissman BN: Calcifying tendinitis of the rotator cuff with cortical bone erosion. Skeletal Radiol 2004, 33:596-599.

6. Flemming DJ, Murphey MD, Shekitka KM, Temple HT, Jelinek JJ, Kransdorf MJ: Osseous involvement in calcific tendinitis: a retrospective review of 50 cases. AJR Am J Roentgenol 2003, 181:965-972.

7. Porcellini G, Paladini P, Campi F, Pegreffi F: Osteolytic lesion of greater tuberosity in calcific tendinitis of the shoulder. J Shoulder Elbow Surg 2009, 18:210-215.

8. Riley GP, Harrall RL, Constant CR, Cawston TE, Hazleman BL: Prevalence and possible pathological significance of calcium phosphate salt accumulation in tendon matrix degeneration. Ann Rheum Dis 1996, 55:109-115.

9. Mavrikakis M, Drimis S, Kontoyannis D, Rasidakis A, Moulopoulou E, Kontoyannis S: Calcific shoulder periarthritis (tendinitis) in adult onset diabetes mellitus: a controlled study. Ann Rheum Dis, 1989 1989, 48:211-214.

10. Maffulli N, Wong J, Almekinders LC: Types and epidemiology of tendinopathy. Clin Sports Med 2003, 22:675-692.

11. Key JA: Calcium deposits in the vicinity of the shoulder and of other joints. Ann Surg 1949, 129:737-753.

12. Sandstrom C: Peridentinis calcarea. A common disease of middle life. Its diagnosis pathology and treatment. AJR 1938, 40:1-21.

13. Bishop WA Jr: Calcification of the supraspinatus tendon: cause, pathologic picture and relation to the scalenus anticus syndrome. Arch Surg 1939, 39:231-246.

14. Bosworth BM: Calcium deposits in the shoulder and subacromial bursitis: a survey of 12,122 shoulders. J Am Med Assoc 1941, 116:2477-2482.

15. Urist R, Moss MJ, Adam JM: Calcification of tendon. A triphasic local mechanism. Archives of Pathology 1964, 77:594-608.

16. Uhthoff HK, Sarkar K, Maynard JA: Calcifying tendonitis: A new concept of its pathogenesis. Clin Orthop Relat Res 1976, 118:164-168.

17. Mohr W, Bilger S: Morphologische Grundstrukturen der kalzifizierten Tendopathie und ihre Bedeutung fur die Pathogenese. $Z$ Rheumatol 1990, 49:346-355.

18. McCarty DJ, Gatter RA: Recurrent acute inflammation associated with focal apatite crystal deposition. Arthritis Rheum 1966, 9:804-819.

19. Montel G, Bonel G, Trombe J C, Heughewaert J C, Rey C: Progress dans le domaine de la chirnie des composes phrophores solides a structure d'apatite. Application a la biologie et au traitement des minerais. Pure and Applied Chemistry 1980, 52:973-987.

20. Hamada J, Tamai K, Ono W, Saotome K: Does the nature of deposited basic calcium phosphate crystals determine clinical course in calcific periarthritis of the shoulder? J Rheumathology 2006, 33:326-332.

21. Hamada J, Ono W, Tamai K, Saotome K, Hoshino T: Analysis of calcium deposits in calcific periarthritis. J Rheumatol 2001, 28:809-813.

22. Penel G, Leroy G, Rey C, Bres E: Micro Raman spectral study of the PO4 and $\mathrm{CO} 3$ vibrational modes in synthetic and biological apatites. Calcif Tissue Int 1998, 63:475-481.

23. Gartner J, Simons B: Analysis of calcific deposits in calcifying tendinitis. Clin Orthop Relat Res 1990, 254:111-120.

24. Chiou HJ, Hung SC, in SY, Wei YS, Li MJ: Correlations among mineral components, progressive calcification process and clinical symptoms of calcific tendonitis. Rheumatology 2010, 49:548-555.

25. Gohr CM, Fahey M, Rosenthal AK: Calcific tendonitis: A model. Connective Tissue Research 2007, 48:286-291.

26. Wuthier RE, Lipscomb GF: Matrix vesicles: structure, composition, formation and function in calcification. Front Biosci 2011, 1:2812-2902.

27. Archer R, Bayley J, Archer C, Ali S: Cell and matrix changes associated with pathological calcification of the human rotator cuff tendons. J Anat 1993, 182:1-12.

28. Uhthoff HK, Loehr JW: Calcific tendinopathy of the rotator cuff: pathogenesis, diagnosis and management. J AM Acad Orthop Surg 1997, 5:183-191

29. Nakase T, Takeuchi E, Sugamoto K, Kaneko M, Tomita T, Myoui A, Uchiyama $\mathrm{Y}$, Ochi T, Yoshikawa H: Involvement of multinucleated giant cells synthesizing cathepsin $\mathrm{K}$ in calcified tendinitis of the rotator cuff tendons. Rheumatology 2000, 39:1074-1077.

30. Inaoka T, Bilbe G, Ishibashi O, Tezuka K, Kumegawa M, Kokubo T: Molecular cloning of human cDNA for cathepsin K: novel cysteine proteinase predominantly expressed in bone. Biochem Biophys Res Commun 1995, 206:89-96.
31. Takeuchi E, Sugamoto K, Nakase T, Miyamoto T, Kaneko M, Tomita T, Myoui A, Ochi T, Yoshikawa H: Localization and expression of osteopontin in the rotator cuff tendons in patients with calcifying tendinitis. Virchows Arch 2001, 438:612-617, 24.

32. Halverson PB: Crystal deposition disease of the shoulder (including calcific tendonitis and Milwaukee shoulder syndrome). Curr Rheumatol Rep 2003, 5:244-247.

33. Choi ST, Kim JH, Kang EJ, Lee SW, Park MC, Park YB, Lee SK: Osteopontin might be involved in bone remodeling rather than in inflammation in ankylosing spondylitis. Rheumatology (Oxford) 2008, 47:1775-1779.

34. Benjamin M, Rufai A, Ralphs JR: The mechanism of formation of bonny spurs (enthesophytes) in the Achilles tendon. Arthritis \& Rheumatism 2000 43:576-583.

35. Lui PP, Fu SC, Chan LS, Hung LK, Chan KM: Chondrocyte phenotype and ectopic ossification in collagenase-induced tendon degeneration. J Histochem Cytochem 2009, 57:91-100.

36. Lui PP, Chan LS, Lee YW, Fu SC, Chan KM: Sustained expression of proteoglycans and collagen type III/type I ratio in a calcified tendinopathy model. Rheumatology 2010, 49:231-239.

37. Maffulli N, Reaper J, Ewen SW, Waterston SW, Barrass V: Chondral metaplasia in calcific insertional tendinopathy of the Achilles tendon. Clin J Sport Med 2006, 16:329-334

38. de Mos M, van El B, DeGroot J, Jahr H, van Schie HT, van Arkel ER, Tol H, Heijboer R, van Osch GJ, Verhaar JA: Achilles tendinosis: changes in biochemical composition and collagen turnover rate. Am J Sports Med 2007, 35:1549-1556.

39. Sharma P, Maffulli N: Tendon injury and tendinopathy: healing and repair. J Bone Joint Surg Am 2005, 87:187-202.

40. Hashimoto Y, Yoshida G, Toyoda H, Takaoka K: Generation of tendon-tobone interface 'enthesis' with the use of recombinant BMP-2 in a rabbit model. J Orthop Res 2007, 25:1415-1424.

41. Zhang J, Wang JH: BMP-2 mediates PGE(2)-induced reduction of proliferation and osteogenic differentiation of human tendon stem cells. J Orthop Res 2012, 30:47-52.

42. de Mos M, Koevoet WJ, Jahr H, Verstegen MM, Heijboer MP, Kops N, van Leeuwen JP, Weinans H, Verhaar JA, van Osch GJ: Intrinsic differentiation potential of adolescent human tendon tissue: an in vitro cell differentiation study. BMC Musculoskelet Disord 2007, 23:8-16.

43. Salingarnboriboon R, Yoshitake $H$, Tsuji K, Obinata M, Amagasa T, Nifuji A, Noda M: Establishment of tendon-cell lines exhibiting pluripotent mesenchymal stem cell-like property. Exp Cell Res 2003, 28:289-300.

44. Rui YF, Lui PP, Li G, Fu SC, Lee YW, Chan KM: Isolation and characterization of multipotent rat tendon-derived stem cells. Tissue Eng Part A 2010, 16:1549-1558.

45. Rui YF, Lui PP, Ni M, Chan LS, Lee YW, Chan KM: Mechanical loading increased BMP-2 expression which promoted osteogenic differentiation of tendon-derived stem cells. J Orthop Res 2010, 29:390-396.

46. Rui YF, Lui PP, Chan LS, Chan KM, Fu SC, Li G: Does erroneous differentiation of tendon-derived stem cells contribute to the pathogenesis of calcifying tendinopathy? Chin Med J 2011, 124:606-610.

47. Zhang J, Wang JH: BMP-2 mediates PGE(2)-induced reduction of proliferation and osteogenic differentiation of human tendon stem cells. J Orthop Res 2012, 30:47-52.

48. Oliva F, Barisani D, Grasso A, Maffulli N: Gene expression analysis in calcific tendinopathy of the rotator cuff. Eur cell Mater 2011, 21:548-557.

49. Oliva F, Zocchi L, Codispoti A, Candi E, Celi M, Melino G, Maffulli N, Tarantino U: Transglutaminases expression in human supraspinatus tendon ruptures and in mouse tendons. Biochem Biophys Res Commun 2009, 379:887-891.

50. Corps AN, Robinson AH, Movin T, Costa ML, Hazleman BL, Riley GP: Increased expression of aggrecan and biglycan mRNA in Achilles tendinopathy. Rheumatology (Oxford) 2006, 45:291-294.

51. Takeuchi $Y$, Kodama $Y$, Matsumoto T: Bone matrix decorin binds transforming growth factor-beta and enhances its bioactivity. $J$ Biol Chem 1994, 269:32634-32638.

52. Svensson L, Närlid I, Oldberg A: Fibromodulin and lumican bind to the same region on collagen type I fibrils. FEBS Lett 2000, 470:178-182.

53. Ameye L, Aria D, Jepsen K, Oldberg A, Xu T, Young MF: Abnormal collagen fibrils in tendons of biglycan/fibromodulin-deficient mice lead to gait impairment, ectopic ossification, and osteoarthritis. FASEB J 2002, 16:673-680. 
54. Hildebrand A, Romarís $M$, Rasmussen LM, Heinegård D, Twardzik DR Border WA, Ruoslahti E: Interaction of the small interstitial proteoglycans biglycan, decorin and fibromodulin with transforming growth factor beta. Biochem J 1994, 302:527-534.

55. Schlessinger J, Lax I, Lemmon M: Regulation of growth factor activation by proteoglycans: what is the role of the low affinity receptors? Cell 1995, 83:357-360.

56. Bi Y, Ehirchiou D, Kilts TM, Inkson CA, Embree MC, Sonoyama W, Li L, Leet Al, Seo BM, Zhang L, Shi S, Young MF: Identification of tendon stem/ progenitor cells and the role of the extracellular matrix in their niche. Nat Med 2007, 13:1219-1227.

57. Lui PPY, Chan LS, Cheuk YC, Lee Yw, Chan KM: Expression of bone morphogenetic protein-2 in the chondrogenic and ossifying site of calcific tendinopathy and traumatic tendon injury rat model. $J$ Orthop Surg Res 2009, 21:4-27.

58. Speer MY, Yang HY, Brabb T, Leaf E, Look A, Lin WL, Frutkin A, Dichek D, Giachelli CM: Smooth muscle cells give rise to osteochondrogenic precursors and chondrocytes in calcifying arteries. Circulation Res 2009, 104:733-741.

59. Kim SY, Choi HY, Myung KB, Choi YW: The expression of molecular mediators in the idiopathic cutaneous calcification and ossification. $J$ Cutan Pathol 2008, 35:826-831.

60. Lounev VY, Ramachandran R, Wosczyna MN, Yamamoto M, Maidment AD, Shore EM, Glaser DL, Goldhamer DJ, Kaplan FS: Identification of progenitor cells that contribute to heterotopic skeletogenesis. J Bone Joint Surg Am 2009, 91:652-663.

61. Harvie P, Pollard TC, Carr AJ: Calcific tendinitis: Natural history and association with endocrine disorders. J Shoulder Elbow Surg 2007, 16:169-173.

62. Rosenthal AK, Gohr CM, Mitton E, Monnier VM, Burner T: Advanced glycation endproducts increase transglutaminase activity in primary porcine tenocytes. J Invest Med 2009, 57:460-466.

63. Hurt G, Baker CL Jr: Calcific tendinitis of the shoulder. Orthop Clin N Am 2003, 34:567-575.

64. Hajiroussou VJ, Webley M: Familial calcific periarthritis. Annals of the Rheumatic Diseases 1983, 42:469-470.

65. Cannon RB, Schmid FR: Calcific periarthritis involving multiple sites in identical twins. Arthritis Rheum 1973, 16:393-396.

66. Zaphiropoulos G, Grahame R: Recurrent calcific periarthritis involving multiple sites. Proc R Soc Med 1973, 66:351-352.

67. Marcos JC, De Benyacar MA, García-Morteo O, Arturi AS, MaldonadoCocco JA, Morales VH, Laguens RP: Idiopathic familial chondrocalcinosis due to apatite crystal deposition. Am J Med 1981, 71:557-564.

68. Mokone GG, Schwellnus MP, Noakes TD, Collins M: The COL5A1 gene and Achilles tendon pathology. Scand J Med Sci Sports 2006, 16:19-26.

69. Mokone GG, Gajjar M, September AV, Schwellnus MP, Greenberg J, Noakes TD, Collins M: The guanine-thymine dinucleotide repeat polymorphism within the tenascin- $C$ gene is associated with Achilles tendon injuries. Am J Sports Med 2005, 33:1016-1021.

70. Raleigh SM, van der Merwe L, Ribbans WJ, Smith RK, Schwellnus MP, Collins M: Variants within the MMP3 gene are associated with Achilles tendinopathy: possible interaction with the COL5A1 gene. $\mathrm{Br} J$ Sports Med 2009, 43:514-520.

71. Fong CM: Calcific tendinitis of the supraspinatus tendon in a 7-year-old boy: diagnostic challenges. Hong Kong Med J 2011, 17:414-416.

72. Lippi G, Longo UG, Maffulli N: Genetics and sports. Br Med Bull 2010, 93:27-47.

73. Fenwick S, Harrall R, Hackney R, Bord S, Horner A, Hazleman B, Riley G: Endochondral ossification in Achilles and patella tendinopathy. Rheumatology (Oxford) 2002, 41:474-476.

74. Al-Sadi O, Schulze-Tanzil G, Kohl B, Lohan A, Lemke M, Ertel W, John T: Tenocytes, pro-inflammatory cytokines and leukocytes: a relationship? MLTJ 2012, 1:68-76.

75. Chan KM, Fu SC: Anti-inflammatory management for tendon injuries friends or foes? Sports Med Arthrosc Rehabil Ther Technol 2009, 1:23.

76. Riley GP, Cox M, Harrall RL, Clements S, Hazleman BL: Inhibition of tendon cell proliferation and matrix glycosaminoglycan synthesis by nonsteroidal anti-inflammatory drugs in vitro. J Hand Surg Br 2001, 26:224-228.
77. Tsai WC, Hsu CC, Chou SW, Chung CY, Chen J, Pang JH: Effects of celecoxib on migration, proliferation and collagen expression of tendon cells. Connect Tissue Res 2007, 48:46-51.

78. Tempfer H, Gehwolf R, Lehner C, Wagner A, Mtsariashvili M, Bauer HC, Resch $\mathrm{H}$, Tauber M: Effects of crystalline glucocorticoid triamcinolone acetonide on cultered human supraspinatus tendon cells. Acta Orthop 2009, 80:357-362.

79. Murata H, Tanaka H, Taguchi T, Shiigi E, Mizokami H, Sugiyama T, Kawai S: Dexamethasone induces human spinal ligament derived cells toward osteogenic differentiation. J Cell Biochem 2004, 92:715-722.

80. Longo UG, Forriol F, Campi S, Maffulli N, Denaro V: Animal Models for Translational Research on Shoulder Pathologies: From Bench to Bedside. Sports Med Arthrosc Rev 2011, 19:184-193.

81. Abate M, Oliva F, Schiavone C, Salini V: Achilles tendinopathy in amateur runners: role of adiposity (Tendinopathies and obesity). MLTJ 2012, 2:44-48.

82. Del Buono A, Battery L, Denaro V, Maccauro G, Maffulli N: Tendinopathy and inflammation: some truths. Int J Immunopathol Pharmacol 2011 24:45-50.

\section{Pre-publication history}

The pre-publication history for this paper can be accessed here:

http://www.biomedcentral.com/1741-7015/10/95/prepub

doi:10.1186/1741-7015-10-95

Cite this article as: Oliva et al:: Physiopathology of intratendinous calcific deposition. BMC Medicine 2012 10:95.

\section{Submit your next manuscript to BioMed Central and take full advantage of:}

- Convenient online submission

- Thorough peer review

- No space constraints or color figure charges

- Immediate publication on acceptance

- Inclusion in PubMed, CAS, Scopus and Google Scholar

- Research which is freely available for redistribution

Submit your manuscript at www.biomedcentral.com/submit 